\title{
Review on Emerging Waterborne Pathogens in Africa: The Case of Cryptosporidium
}

\author{
Gilver Odilon Mendel Kombo Mpindou ${ }^{1, * \mathbb{C}}$, Ignacio Escuder Bueno ${ }^{1}$ and Estela Chordà Ramón ${ }^{2}$ \\ 1 Institute of Water and Environmental Engineering, Universitat Politècnica de València, Camino de Vera s/n, \\ 46022 Valencia, Spain; iescuder@hma.upv.es \\ 2 Hospital Público Universitario De La Ribera, 46600 Alzira, Spain; estelachorda@gmail.com \\ * Correspondence: kgilver@gmail.com
}

check for updates

Citation: Kombo Mpindou, G.O.M.; Escuder Bueno, I.; Chordà Ramón, E. Review on Emerging Waterborne Pathogens in Africa: The Case of Cryptosporidium. Water 2021, 13, 2966. https://doi.org/10.3390/ w13212966

Academic Editor: Hodon Ryu

Received: 11 September 2021

Accepted: 15 October 2021

Published: 21 October 2021

Publisher's Note: MDPI stays neutral with regard to jurisdictional claims in published maps and institutional affiliations.

Copyright: (C) 2021 by the authors Licensee MDPI, Basel, Switzerland. This article is an open access article distributed under the terms and conditions of the Creative Commons Attribution (CC BY) license (https:/ / creativecommons.org/licenses/by/ $4.0 /)$.
Abstract: Water-related diseases, particularly waterborne diseases, remain significant sources of morbidity and mortality worldwide but especially in developing countries. Emerging waterborne pathogens represent a major health risk. Cryptosporidium is one such pathogen which is globally recognized as a major cause of diarrhea in children and adults. The objective of this paper is not only to review published studies on the impact of these emerging waterborne pathogens but also to identify the various risk factors that favor their transmission. A number of envisaged and needed actions to tackle the challenge of these pathogens in Africa have also been discussed. We have searched the web of ScienceDirect, PubMed, Scopus. ISI Web of Science, SpringerLink, and Google Scholar. The first database search yielded 3099 articles. As a result, 141 studies were submitted for abstract review. A total of 68 articles were selected for full text analysis. After evaluating a considerable number of articles on this topic, the following results were obtained. A number of pathogens are likely to present public health risks, including Cryptosporidium. The contaminating potential of these pathogens is associated with a multitude of factors, such as the effects of climate change, social and behavioral aspects of local populations, water issues, geographical locations that may cause isolation, and inequalities due to lack of transparency of governments in the distribution of financial resources. We stress the need to maintain and strengthen real-time surveillance and rapid epidemiological responses to outbreaks and the emergence of new waterborne pathogens in all countries. African governments, for their part, should be aware of future risks of waterborne protozoan diseases. They must provide immediate and effective responses by establishing technical and financial mechanisms to ensure sufficient quantities of safe drinking water, sewage disposal, and hygiene for all.

Keywords: Cryptosporidium; risk factors; waterborne diseases; Africa; review

\section{Introduction}

Diarrheal diseases have been classified as the fourth leading cause of death in children, after iron deficiency anemia, skin diseases, and protein-energy malnutrition. In Africa, the World Health Organization (WHO) has classified diarrheal diseases of viral, bacterial, and parasitic origin as leading causes of human mortality [1]. The Institute of Medicine declared in 1992 that an emerging infection is any new, re-emerging or drug-resistant infection that is likely to increase in frequency in the near future [2]. A large number of publications and journals on the topic address the issue of emerging and re-emerging pathogens in general, including waterborne pathogens, without addressing issues specifically related to emerging waterborne pathogens. Although responsible for waterborne epidemics worldwide, the disease burden due to Cryptosporidium is highest in Africa [3-5]. These pathogenic microorganisms are likely to be transmitted through contaminated drinking water, including both treated and untreated wastewater [6]. Surface waters are frequently polluted by unregulated wastewater discharges, poorly controlled wastewater treatment facilities, and inadequate waste disposal facilities in residential areas near rivers $[7,8]$. 
Unsafe water supply and poor sanitation and hygiene conditions increase the transmission of diarrheal diseases. In addition to the challenges Africa faces regarding unsafe water supply, the high prevalence of HIV and malnourishment which leaves many of these communities even more vulnerable to diarrheal diseases caused by these parasites. Enteric protozoa are generally ignored and neglected as a cause of diarrhea because these regions have better hygiene conditions [9]. In addition, Africa is a continent highly exposed to climate change, especially sub-Saharan African countries, and waterborne protozoa are very sensitive to climate change, especially temperature and rainfall. Changes in rainfall and drought in some parts of Africa are influencing the availability of freshwater [10]. Cryptosporidiosis has been shown to be an important and independent determinant of infant mortality in Africa [11,12]. Morbidity in both developed and developing countries may be largely underestimated based on the number of asymptomatic and self-limited infections. Meanwhile, the lack of effective diagnosis of diarrhea-causing pathogens, as well as the use of microscopy for routine clinical diagnosis (with very low specificity and sensitivity), may also contribute to an underestimation of Cryptosporidium infection [5]. In Africa, cryptosporidiosis is an important factor of morbidity and mortality. It is therefore crucial to target keystone factors which could help limit the spread of Cryptosporidium. The United Nations Sustainable Development Goals (SDGs) 3, 6, and 11, which focus on the health and well-being of people, safe drinking water and sanitation, and sustainable cities and communities, directly or indirectly address this issue [13]. The African Union's Agenda 2063 calls for the African continent to be based on inclusive growth and sustainable development. In order to achieve these goals, it is necessary to have a good understanding of how waterborne diseases are affecting the population, whether in urban or rural areas. Research been conducted on water quality, water scarcity, and rural/urban water redistribution in Africa [14].

On the flipside, other research has focused on the environmental determinants of waterborne disease outbreaks in Africa, as well as the link between waterborne diseases and water resources development in Africa and global warming. To ensure an average level of sanitary protection, access to at least $50 \mathrm{~L}$ of safe clean water per person/day would be required. However, there are a number of identified risk factors that affect water quality and are responsible for waterborne diseases and syndromes. The objective of this manuscript is not only to review published studies on the impact of emerging waterborne pathogens, in particular Cryptosporidium in Africa, by identifying the different risk factors that favor their spread, but also to provide food for thought on current and future challenges [15].

More specifically, our aim is to answer the following questions:

- How has the relationship between waterborne diseases and water consumption been analyzed in Africa?

- Are there any overlooked water consumption parameters, waterborne syndromes or diseases?

-What are the causes of the spread of these diseases in Africa?

\section{Methods}

\subsection{Scope and Strategies of the Current Review}

A methodical approach was used for this review, including: (i) a systematic review of the literature to identify articles that met the inclusion criteria; (ii) the relevance of the articles to the study themes; (iii) the performance of full-text analyses of the articles; and (iv) the extraction and synthesis of results. The general protocol for the scoping review was inspired by various previous studies. The main research questions guiding this review ere: "what is the prevalence of waterborne diseases in Africa in general?", "what are the most commonly reported sources/pathways of contamination?", and "what detection methods can be used for its identification?". 


\subsection{Inclusion and Exclusion Criteria}

The selection of the main search keywords was based on a modified version of the population outcome agent (POA) model, including concrete search strategies used to conduct structured literature searches [16]. Searches conducted using a different category of "Result" search term (e.g., Cryptosporidiosis, contamination, epidemic, etc.) fell considerably short of the number of articles identified. Therefore, the search terms of the categories "agent" and "outcome" were combined to broaden the search field. The databases were searched using Boolean operators ("AND", "OR", "WITH", "SAME", "ADJ") to focus the literature review. To analyze the relevance of the different studies included in the literature review, and to assess their quality, we used the Strengthening the Reporting of Observational Studies in Epidemiology (STROBE) checklist [17]. (See Table 1; the list of the variables extracted from the articles during the selection process).

Table 1. Presentation of the variables extracted from the different articles during the full-text selection phase.

\begin{tabular}{|c|c|}
\hline Variable & Description/Example \\
\hline \multicolumn{2}{|l|}{ Study design } \\
\hline Study period & Year(s) \\
\hline Geographical scope of the study & City/cities where the study was conducted \\
\hline Population inclusion criteria & Households/women/children/confirmed cases etc. \\
\hline Sample size (people) & Number of respondents /households \\
\hline Sample size & Number of water/stool/soil samples for testing \\
\hline Outbreak investigation & Yes/No \\
\hline \multicolumn{2}{|l|}{ Indicators of piped water sufficiency } \\
\hline Nature of piped water supply & Continuous/scheduled interruptions/unpredictable interruptions \\
\hline Mode of water access & Inhouse piped connection, shared tap at yard, public tap/water kiosk \\
\hline Measurement of per capita daily water consumption & Yes/No \\
\hline \multicolumn{2}{|l|}{$\begin{array}{l}\text { Coping mechanism employed to } \\
\text { supplement water needs }\end{array}$} \\
\hline Use of storage tanks & Yes/No \\
\hline $\begin{array}{l}\text { Storage of water in households in } \\
\text { containers, bottles etc. }\end{array}$ & Yes/No \\
\hline $\begin{array}{l}\text { Collecting water from rivers/streams, } \\
\text { shallow wells, rainwater }\end{array}$ & Yes/No \\
\hline Drilling of wells/boreholes & Yes/No \\
\hline Installation of hand pumps/electric pumps & Yes/No \\
\hline \multicolumn{2}{|l|}{ for groundwater $\mathrm{T}$ T } \\
\hline Water treatment & Yes/No \\
\hline Inadequate wastewater management & Yes/No \\
\hline Water recycling & Yes/No \\
\hline Illegal water connections & Yes/No \\
\hline \multicolumn{2}{|l|}{ Indicators of health } \\
\hline Cholera & Self-reported/diagnosed/laboratory confirmed \\
\hline Cyclosporiasis & Self-reported/diagnosed/laboratory confirmed \\
\hline Gastroenteritis & Self-reported/diagnosed/laboratory confirmed \\
\hline Cryptosporidium & Self-reported/diagnosed/laboratory confirmed \\
\hline Cryptosporidiosis & Self-reported/diagnosed/laboratory confirmed \\
\hline
\end{tabular}

\section{Results}

\subsection{Characteristics of the Publications}

The first database search yielded 3099 articles. After removing duplicates and assessing abstracts for eligibility, only 141 full-text articles remained to be reviewed, 68 of which met the inclusion criteria.

Based on our checklist, we identified the strengths and weaknesses of the studies. All articles had a specific objective, a study design, and a study site with a date for data collection. Most of the selected studies clearly indicated the selection criteria (Table 2). The target population of the studies was households in general, which confirmed cases 
or patients in hospitals treated for waterborne diseases, and focused on children under 10 years of age, as well as women, mothers of infants, and HIV-infected persons.

Table 2. Results of the studies included in the scope synthesis.

\begin{tabular}{|c|c|c|}
\hline Characteristic & $\mathrm{N}^{\mathrm{o}}$ of Studies & References \\
\hline \multicolumn{3}{|l|}{ Study period } \\
\hline$\leq 2005$ & 9 & {$[1,2,18,19,21,22,24,27,45]$} \\
\hline 2006-2019 & 52 & {$[2-17,20,23,25-30,35-50,54,55-73,75]$} \\
\hline$\geq 2020$ & 7 & {$[9,11,12,14,53,68]$} \\
\hline Type of drinking water, Exposure Population, Rural & 11 & {$[44,48,50,53,55,61,63-65,72,74,83]$} \\
\hline $\begin{array}{l}\text { Source of drinking water a (e.g, bottled, rain, } \\
\text { cistern, etc.) }\end{array}$ & 6 & {$[35,36,38,43,58,59]$} \\
\hline $\begin{array}{l}\text { Microbiological/Pathogen Cyclosporas, } \\
\text { Gastroenteritis Cryptosporidium Cryptosporidiosis }\end{array}$ & 24 & {$[3,7,13,19,22,24,26,33,34,39,41,42,45,50,52,55-58,62]$} \\
\hline Government departments/agencies & 4 & {$[17,23,28,63]$} \\
\hline Cross-sectional individual-level and case control & 1 & [63] \\
\hline Population inclusion criteria & 7 & {$[34,38,41,43-45,49,51]$} \\
\hline Households/respondents & & \\
\hline $\begin{array}{l}\text { Confirmed cases/people visiting health facilities for } \\
\text { treatment of waterborne disease }\end{array}$ & 6 & {$[37,45,47,48,54,61]$} \\
\hline Children/infants & 6 & {$[33,35,42,49,51,56]$} \\
\hline Women or mothers of infants' HIV positive persons & 6 & {$[33,35,42,49,51,56]$} \\
\hline Study investigating an outbreak & 5 & {$[1,4,10,49,50]$} \\
\hline Climate & 3 & {$[10,73,76]$} \\
\hline Factor risk & 5 & {$[8,17,23,29,34,77]$} \\
\hline
\end{tabular}

The results of this synthesis provide an overview of the impact of waterborne diseases in Africa, including cryptosporidiosis caused by emerging pathogens. It highlights currently available information on the epidemiology of Cryptosporidium, as well as its treatment and distribution on the African continent, particularly among vulnerable populations including children. It also highlights risk factors to enable African governments to address current and future challenges.

\subsection{Cryptosporidium}

As a result of the lack of sporocysts in the oocyst (i.e., naked sporozoites), Cryptosporidium has been considered enigmatic since it was described for the first time by Edward Tyzzer in 1907 from the gastric glands of a mouse [18]. He placed it in the coccidian family Asporocystidae because of the oocyst's lack of sporocysts (i.e., sporozoites) and what was presumed to be the possession of similar life cycle characteristics [19]. In the 70 years since Tyzzer's description, this Cryptosporidium has been regarded as a curiosity. More species were described, mainly on the basis of the presence of hosts, but this parasite was always seen as atypical. These biological characteristics, however, were overshadowed by the serious public health implications of the opportunistic Cryptosporidium infections that emerged in the 1980s, mainly by taking advantage of the weakened immune systems of AIDS patients [20]. This health emergence highlighted the use of chemotherapies and the early evidence that Cryptosporidium is completely insensitive to anticoccidial drugs [21,22]. Numerous species of Cryptosporidium exist which infect humans and a large number of animals. Although Cryptosporidium parvum and Cryptosporidium hominis (formerly known as the anthroponotic genotype or genotype 1 of $\mathrm{C}$. parvum) are the main organisms causing disease in humans, infections with C. felis, C. meleagridis, C. canis and C. muris have also been reported. Infections with Cryptosporidium parvum and C. hominis species are mainly through water contamination (e.g., drinking or recreational water). Occasionally, certain foods, such as chicken salad, are likely to promote transmission. Direct faecal/oral spread is likely to be the most common form of transmission, both for zoonotic diseases and for direct transmission from parent to child $[23,24]$. Waterborne epidemics are a major issue worldwide. They are a financial burden for water companies. Indeed, it has been revealed 
that the phenomenon is amplified by the fact that biofilms constitute Cryptosporidium reservoirs in which oocysts are not only trapped and then released into the water distribution system, but also highly nutritious environments allowing the parasite to grow and reproduce $[25,26]$ (Figure 1).

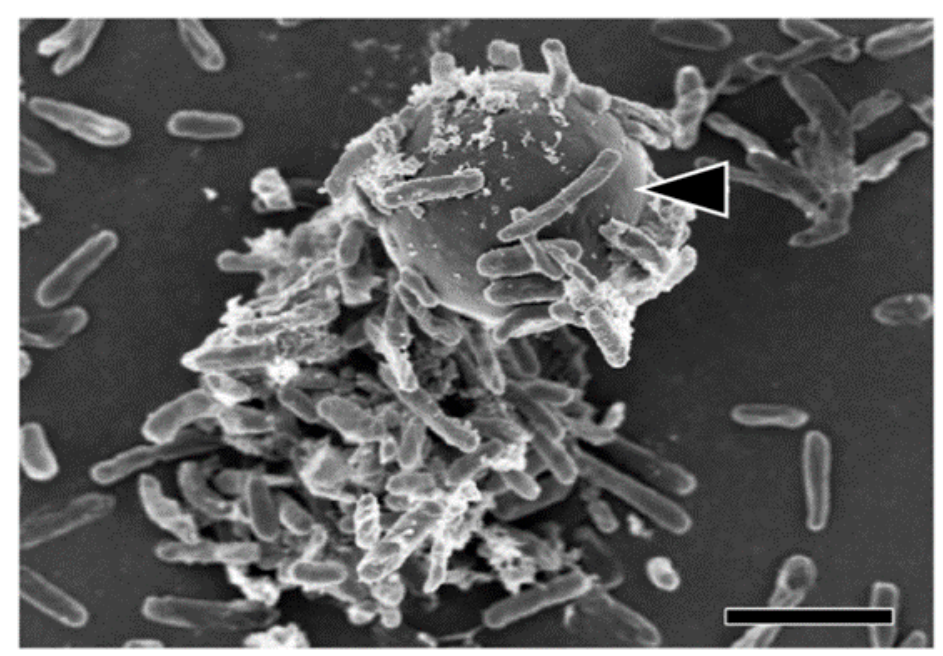

Figure 1. Scanning electron micrograph showing a Cryptosporidium oocyst (see [26] for methods). Scale bar $=3 \mu \mathrm{m}$.

In developing and developed countries, the spread of parasites by waterborne means is therefore likely to be a consequence of contaminated or malfunctioning water facilities. Infections by indirect transmission, i.e., by uncontrolled transmission of oocysts from flies [27] or other animals, such as dogs or cattle, or through contaminated food or local water sources. They are a real danger, especially in developing countries $[28,29]$. Rural areas are at greater risk of infection than urban areas, probably due to the higher risk of direct and indirect contamination in areas with poor hygiene and higher rates of contact with wildlife and pets [30]. Poor hygiene is a key factor in the transmission of enteric protozoa, such as Cryptosporidium [30].

\subsubsection{Emerging Water-Borne Pathogens}

In order to better understand the causes of emergence, a distinction must be made between emerging waterborne pathogens and newly recognized pathogens. The majority of emerging waterborne pathogens fall into the former category, implying that, although the etiological agent has been known for a very long time, it has only recently been recognized as the main cause of waterborne diseases. These include parasitic protozoa, such as Cryptosporidium Microsporidia; Campylobacter; several viruses, including caliciviruses and hepatitis E virus; and a multitude of environmental bacteria, namely Mycobacterium, aeromonads, Pneumophila, and aeruginosa. There are several possible reasons for the emergence of newly recognized pathogens. One of the most important reasons, which probably concerns everyone, is the development of efficient detection methods, including molecular, immunological, and immunomagnetic techniques [31]. Another, perhaps more important, reason for the emergence of Cryptosporidium is the increase in the number of immunocompromised people, such as patients receiving cancer treatment or organ transplants, the elderly, and AIDS patients. The emergence of these pathogens is probably related to the relatively greater numbers in immunocompromised among the population. The growth of urbanization, which requires the use of large drinking water systems and its resulting issues, is mainly responsible for the emergence of waterborne diseases. Recently, the increasing migration of humans from one region to another has proven to introduce pathogens as well [32]. 


\subsubsection{Human Health Impacts}

Cryptosporidiosis has a very high impact in the majority of lower-GDP countries in the continent. Guinea-Bissau was one of the first states in Africa where the impact of Cryptosporidium was examined. It confirmed that Cryptosporidium was a cause of excess mortality in children under 12 months of age and that this excessive mortality rate continued into the second year of life. Although cryptosporidiosis was considered to have such an impact in some countries, the first comprehensive information confirming this has recently been provided, based on the results of the Global Burden of Disease (GBD) and the Global Enteric Multicentre Study (GEMS), e.g., [4,33]. These various studies have generated the first global estimates of the impact of cryptosporidiosis (among other diseases) (Table 3).

An important analysis was conducted in 2018, revealing that previous reports were likely to have underestimated the high burden by not taking into account impacts occurring after the acute phase of infection, such as reduced growth, weight gain, and an increased risk of subsequent episodes of infection [34]. Other studies have also shown how Cryptosporidium diarrhea can damage the endothelial cells and microvilli of the gut, thus impairing the ability to absorb macronutrients and micronutrients [35]. Malnutrition caused by Cryptosporidium also causes secondary impairment of cell mediated immunity also linked to increased susceptibility to other infectious diseases. Other longterm consequences include reduced cognitive development, poor school performance, and increased risk of cardiovascular and metabolic diseases later in life [36,37]. Cryptosporidium infection in under-fives can be considered to be associated with 44.8 million diarrheal episodes and 48,300 deaths worldwide [38]. The majority of cases are in Africa, where $75 \%$ of diarrheal episodes and $88 \%$ of deaths have been recorded [33]. With regard to Cryptosporidium-associated diarrhea, the proportion of Cryptosporidium-associated deaths in children under five years of age is highest in sub-Saharan Africa, particularly in Nigeria and the Democratic Republic of Congo (DRC) [39]. By including the consequences of growth failure associated with cryptosporidiosis, it has been estimated that the parasite burden may be higher than previously observed [39].

Table 3. Some environmental reservoirs of Cryptosporidium in Africa.

\begin{tabular}{|c|c|c|c|}
\hline Country & $\begin{array}{l}\text { Environmental } \\
\text { Sources/Reservoirs }\end{array}$ & Method of Detection & References \\
\hline Cameroon & $\begin{array}{c}\text { Lake water, } \\
\text { wastewater, rivers }\end{array}$ & $\begin{array}{l}\text { Ziehl-Neelsen method and Lugol } \\
\text { iodine coloration }\end{array}$ & {$[46,47]$} \\
\hline $\begin{array}{l}\text { Côte } \\
\text { d'Ivoire }\end{array}$ & $\begin{array}{l}\text { Urban wastewater } \\
\text { and lagoon water }\end{array}$ & $\begin{array}{c}\text { Sodium acetate formalin (SAF) } \\
\text { technique }\end{array}$ & [48] \\
\hline Egypt & $\begin{array}{l}\text { Swimming pool, } \\
\text { leafy vegetables }\end{array}$ & $\begin{array}{l}\text { Microscopy using Lugol's iodine and } \\
\text { modified Ziehl-Neelsen }\end{array}$ & {$[49,50]$} \\
\hline Ethiopia & $\begin{array}{l}\text { Drinking water } \\
\text { sources }\end{array}$ & U.S. EPA method 1623 & {$[51]$} \\
\hline Ethiopia & Fruits and vegetables & Sedimentation concentration & {$[52]$} \\
\hline Ghana & Sachet water & Not mentioned (outsourced) & {$[53]$} \\
\hline Kenya & $\begin{array}{c}\text { River and } \\
\text { surface water }\end{array}$ & $\begin{array}{l}\text { Filtration and immunomagnetic bead } \\
\text { separation (IMS)-immunoantibody } \\
\text { staining method, calcium carbonate } \\
\text { flocculation (CCF) and sucrose floatation } \\
\text { method, polymerase chain reaction } \\
\text { coupled with the restriction fragment } \\
\text { length polymorphism (PCR-RFLP); }\end{array}$ & {$[54,55]$} \\
\hline Morocco & $\begin{array}{l}\text { Coriander, carrots, } \\
\text { radish, mint, potatoes, } \\
\text { irrigation water }\end{array}$ & Not described & {$[56]$} \\
\hline Nigeria & Surface waters & $\begin{array}{c}\text { Filtration, backwashing, concentration } \\
\text { and modified Ziehl-Neelsen } \\
\text { staining technique }\end{array}$ & {$[57]$} \\
\hline
\end{tabular}


Table 3. Cont.

\begin{tabular}{|c|c|c|c|}
\hline Country & $\begin{array}{c}\text { Environmental } \\
\text { Sources/Reservoirs }\end{array}$ & Method of Detection & References \\
\hline Tanzania & Surface waters & $\begin{array}{l}\text { Microscopy using Lugol's iodine and } \\
\text { modified Ziehl-Neelsen }\end{array}$ & {$[58]$} \\
\hline Tunisia & $\begin{array}{l}\text { Raw and treated } \\
\text { wastewater; sludge }\end{array}$ & Microscopy, PCR, sequencing & {$[59,60]$} \\
\hline South Africa & $\begin{array}{l}\text { Harvested rainwater, } \\
\text { treated wastewater } \\
\text { effluent, irrigation } \\
\text { water, vegetables }\end{array}$ & $\begin{array}{l}\text { PCR, modified Ziehl-Neelsen } \\
\text { acid-fast technique }\end{array}$ & {$[61,62]$} \\
\hline Uganda & $\begin{array}{l}\text { Natural and } \\
\text { communal piped } \\
\text { tap water }\end{array}$ & $\begin{array}{l}\text { Ziehl-Neelsen stain and Giardia cysts } \\
\text { by zinc sulfate floatation technique, } \\
\text { PCR, sequencing }\end{array}$ & {$[63]$} \\
\hline Zimbabwe & $\begin{array}{l}\text { Surface waters, wells, } \\
\text { springs, taps }\end{array}$ & $\begin{array}{l}\text { Zinc sulfate floatation } \\
\text { technique, microscopy }\end{array}$ & {$[64]$} \\
\hline
\end{tabular}

\subsubsection{Veterinary Health Impacts}

Cryptosporidium infection in ruminants in general and infected young animals is highly likely to develop watery diarrhea and dehydration; death is common, especially in neonates. It is very difficult to ensure that exposure to an infectious dose in young animals is controlled [11]. It has also been shown that severe cryptosporidiosis in calves and lambs is likely to have long-term impacts on growth, weight gain, and productivity, in addition to the direct impact of acute infection, as in humans [40]. Since several other etiological agents besides Cryptosporidium can cause diarrhea in calves (e.g., rotavirus; coronavirus; bovine viral diarrhea virus; E. Coli; Clostridium perfringens; Salmonella spp.; and coccidia, such as Eimeria Zuernii and E. Bovis), these data do not indicate the presence of cryptosporidiosis [41].

Some researchers report that Cryptosporidium oocysts are very regularly identified in diarrheic calves in various African countries [42]. It is not clear though whether cryptosporidiosis is the cause of those symptoms. Many of these investigations use the modified Ziehl-Neelsen $(\mathrm{mZn})$ test for determination. This type of test has a relatively low sensitivity but also a high specificity that does not identify the Cryptosporidium species. For example, in the context of a survey in Tanzania, researchers also used antibody immunofluorescence (IFAT) and molecular techniques to test for Cryptosporidium infection in calves. The results of these tests did not show the presence of Cryptosporidium in any of the 943 calf samples, of which more than $6 \%$ had diarrhea, while some of the results obtained with mZn were positive [43]. For these researchers, the information gathered with $\mathrm{mZn}$ should be treated with great caution. In Egypt, another project was conducted using molecular tools and found a $32 \%$ prevalence of Cryptosporidium in cattle [44]. A study in two large dairy farms in central Ethiopia showed that Cryptosporidium infection is common ( $40 \%$ cumulative incidence), with C. Parvum being mainly observed in pre-weaned calves and C. Andersoni in post-weaned calves [44]. All of these are likely to have a disproportionate impact on populations in developing countries [45]. Cryptosporidium are widespread in pets (Table 4), as well as in the environment and food crops, but also in people in Africa, with molecular typing revealing anthroponotic (human-to-human) contamination [13]. 
Table 4. Some animal reservoirs of Cryptosporidium in Africa.

\begin{tabular}{|c|c|c|c|}
\hline Country & $\begin{array}{c}\text { Animal } \\
\text { Sources/Reservoirs }\end{array}$ & Method of Detection & References \\
\hline Algeria & $\begin{array}{l}\text { Lamb, goat, cattle, } \\
\text { chicken, Turkey, } \\
\text { horse, donkey }\end{array}$ & $\begin{array}{c}\text { Nested-PCR, PCR-RFLP, sequencing, } \\
\text { modified Ziehl-Neelsen acid-fast } \\
\text { technique, ELISA }\end{array}$ & [66] \\
\hline $\begin{array}{l}\text { Cameroon } \\
\text { Central }\end{array}$ & Domestic Guinea pig & Sedimentation test, ELISA & {$[66,67]$} \\
\hline $\begin{array}{l}\text { African } \\
\text { republic }\end{array}$ & Gorillas & Nested-PCR, PCR-RFLP, sequencing & [68] \\
\hline Egypt & $\begin{array}{l}\text { Calves, ruminant } \\
\text { animals, dairy cattle }\end{array}$ & $\begin{array}{l}\text { Nested-PCR, Ziehl-Neelsen method, } \\
\text { copro-antigen RIDA®QUICK test, } \\
\text { and real-time PCR }\end{array}$ & [34-71] \\
\hline Ghana & Calves & $\begin{array}{l}\text { Modified Ziehl-Neelsen (MZN) } \\
\text { staining technique }\end{array}$ & [65] \\
\hline Ethiopia & Dairy cattle & $\begin{array}{c}\text { Modified Ziehl-Neelsen (MZN) } \\
\text { microscopy, nested PCR, PCR-RFLP, } \\
\text { sequencing }\end{array}$ & [69-71] \\
\hline South Africa & Calves & $\begin{array}{l}\text { Ziehl-Neelsen (MZN) staining } \\
\text { technique, PCR, sequencing }\end{array}$ & [72] \\
\hline Sudan & Calves & $\begin{array}{l}\text { Modified Ziehl-Neelsen (MZN) } \\
\text { microscopy, nested PCR, PCR-RFLP, } \\
\text { sequencing }\end{array}$ & {$[80]$} \\
\hline Tanzania & $\begin{array}{l}\text { Baboons, chimpanzees, } \\
\text { goats, cattle }\end{array}$ & PCR-RFLP, sequencing & [81] \\
\hline Zambia & Pigs & $\begin{array}{l}\text { Merifluor }{ }^{\circledR C} \text { Cryptosporidium/Giardia } \\
\text { immunofluorescence assay }\end{array}$ & [59] \\
\hline
\end{tabular}

\subsubsection{Incidence}

The prevalence of cryptosporidiosis in children is highly variable in sub-Saharan Africa and in certain sectors of the population. Figure 2 summarizes the prevalence of cryptosporidiosis in children under 5 years of age who visited health facilities with diarrhea [46,47].Although diagnosis is rarely made in this setting, coinfection with other enteric pathogens is common, with common exposure through poor sanitation and hygiene and as a result of immune predisposition due to HIV infection. In most sub-Saharan countries, the prevalence of cryptosporidiosis peaks in children aged 6-12 months and declines thereafter. It can be assumed that breast feeding provides a form of protection, by conferring immunoglobin or preventing water contamination [48]. This may explain why infection is delayed until after the age of 6 months, an age that is usually characterized by the onset of complementary feeding. Children are often infected throughout their childhood and adolescence, while their clinical impact reduces with age [48]. This is probably due to the development of immunity following repeated exposure to oocysts in the contaminated environment [49]. Experimental research shows that repeated exposure to Cryptosporidium parvum results in an IgG response that offers partial protection against subsequent infection and disease [50]. The extent to which this serological response protects against infection by other Cryptosporidium species is still unknown. Epidemiological scenarios that promote and exacerbate Cryptosporidium infections are mainly access to safe water, prevalence of HIV infections, and malnutrition [45-47]. 
A

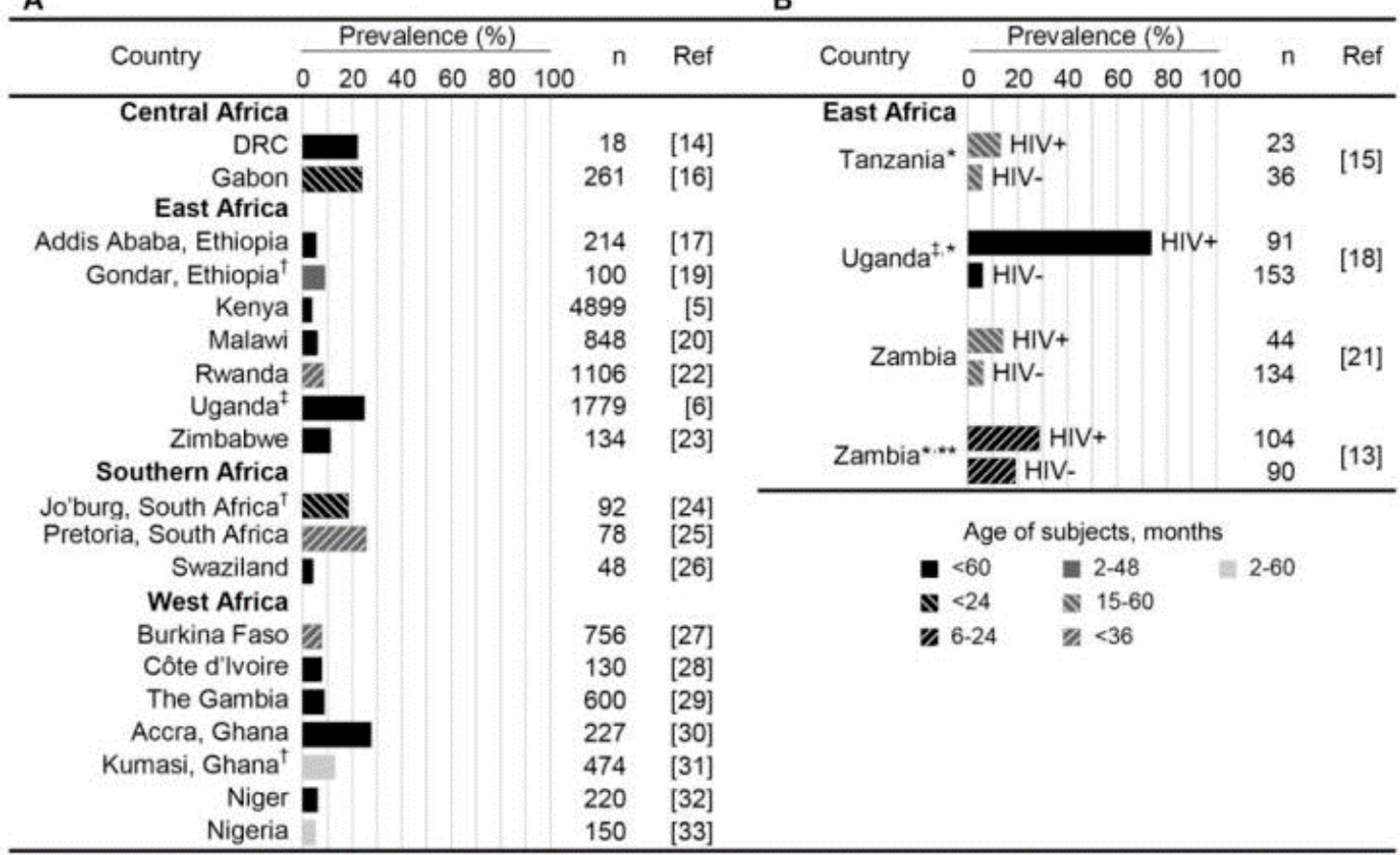

Figure 2. Prevalence of cryptosporidiosis in Africa [5,6,13,51]. Estimates shown are from studies of children under 5 years of age attending health facilities with diarrhoea. Prevalence is reported separately for children with unknown or unreported HIV status (A) and known (B).

\subsubsection{Recognition and Diagnosis}

The recognition and diagnosis of Cryptosporidium has been totally revolutionized by the use of sophisticated techniques and methodologies, such as next-generation sequencing, whole-genome sequencing, and digital PCR. With these techniques, it is now easier to better understand microbial environments and their genetic composition, and to carry out counts on scales previously unimaginable. These methods, already widely used for bacteria, have also been applied to the determination and characterization of protozoa such as Cryptosporidium. For example, in patients with dysentery, diagnosis of C. parvum is usually made using acid-fast staining or immunofluorescence on deconcentrated fecal smears. Good concentration methods can enhance detection when oocytes are in small numbers, but some methods, such as formalin acetate concentration, can cause the loss of many oocysts [52]. Although there are many enzymes linked to immunosorbent assay methods which detect fecal Cryptosporidium antigen with $83-95 \%$ sensitivity in diarrheal samples, they are less sensitive in constituted samples and require more time. The use of immunofluorescence antibody microscopy is slightly more effective and faster [53]. Polymerase chain reaction (PCR) is used to diagnose Cryptosporidium in water supplies or in asymptomatic carriers. The popularity of PCR has risen sharply in recent years due to its great potential to directly determine microbial species, including Cryptosporidium [52]. In fact, these technologies, which are fueled by recent advances in microfluidics, are involved in determining the absolute quantification of nucleic acid in samples without the need for large sample volumes and calibration [54]. Despite the remarkable success of this technology, it has been shown to be twice as expensive (consumables and labor) as PCR for the determination and quantification of Cryptosporidium [55]. This would therefore represent a significant problem for its application in most African countries, where financial resources are very limited. Although microscopy is the most widely used technique for Cryptosporidium identification, with immunofluorescence remaining the gold standard [56], this technique cannot distinguish between strains of these organisms or fully characterize the specific strains associated with outbreaks. This issue has been addressed by whole genome sequencing (WGS). Several experts have used WGS to elucidate the 
complete Cryptosporidium genome in samples of various types [55,57]. One of the main challenges of WGS is the ability to isolate sufficient DNA of very high quality [52]. This can be a real challenge when dealing with environmental samples, as these parasites are not widespread in the environment in general. Furthermore, WGS has not been widely applied to microbial species in Africa, probably due to its cost. These instruments are only available in some African countries. In addition, many of the studies that have been conducted using this technique have been carried out in partnership with other countries in Europe and America, where the equipment and technical know-how are available.

\subsubsection{Treatment of Cryptosporidiosis in Africa}

It should be noted that there is currently no effective vaccine against Cryptosporidium and that only one drug, Nitazoxanide (NTZ, Alinia; Romark Laboratories, Tampa, Florida, USA), is available to control Cryptosporidium. This treatment is not recommended for children under one year of age. Nitazoxanide has also been shown to reduce the resistance capacity of the parasite and may be useful in immunocompetent individuals [58]. However, the drug is not very effective against cryptosporidiosis in immunocompromised and HIVpositive individuals [59]. Nitazoxanide is therefore ineffective against the most critical target population in Africa, which has over 25.7 million HIV-infected people [13]. In HIV-coinfected individuals, antiretroviral therapy (ART) has been effective in controlling chronic diarrhea and wasting caused by cryptosporidiosis $[60,61]$. Today, supportive care and ART (for HIV / AIDS patients) form the basis of treatment for cryptosporidiosis. The main challenge for new drug development is therefore the underlying economic factor, as both parasitic infections are classified as neglected diseases with low funding priority and limited commercial interest [62]. For this reason, there is a movement to repurpose current treatments for unlicensed applications, as repurposed drugs are approximately $60 \%$ cheaper to bring to market than de novo developed drugs [62].

\section{Discussion}

We observe in this analysis that the majority of the surveys followed an environmental event riven design, with only four studies being motivated by gastrointestinal disease epidemics. All epidemic-related investigations were conducted in South-Saharan Africa, with most studies based in typical rural settings, followed by urban and mixed settings. The vast majority of studies have focused on the mode of waterborne transmission of emerging pathogenic microorganisms. We have noted that the reasons for the emergence of waterborne pathogens can, at best, only be addressed in terms of possibilities. Unequivocal answers require further investigation. There are several reasons for the emergence of newly recognized pathogens. One of the most important reasons, which is probably of concern to all, is the development of efficient detection methods, including molecular, immunological, and immunomagnetic techniques [31]. Other reasons, more directly related to the emergence of Cryptosporidium, include the ever-increasing number of immunocompromised people, for example patients undergoing cancer treatment or organ transplants, the elderly, people with AIDS, and the malnourished. The influence of sustained climate change on the emergence of waterborne pathogens should be taken into account.

Water is considered to be the main source of contamination, but the results of this study dispute this, as there is no evidence that the water supply is adequate in urban areas. Daily per capita water consumption and mode of access are inversely related to the level of health and safety hazards [63]. Prevention and control methods should aim to minimize and/or stop the transmission of infective oocysts to people and animals [64]. The establishment of wet sites to treat wastewater and runoff from confined animal husbandry has been shown to be not only a very effective means of eliminating pathogenic microorganisms, such as Cryptosporidium spp., but also very economical [65]. People at risk should avoid certain activities that are likely to increase their exposure to Cryptosporidium spp. Hand washing, education and treatment of water at the point of use (especially in Africa), boiling water before drinking, drinking safe water, and using filtration devices can minimize 
and significantly reduce the rate of transmission of infectious oocysts and the frequency of diarrhea. Exposure to feces during sexual intercourse should also be avoided [66]. Partnership projects to develop practical, effective, and innovative strategies are a key means of addressing these challenges and making progress on innovative strategies to stop the spread of Cryptosporidium in resource limited settings. In this context, scientists from the University of Virginia in Charlottesville, Virginia, USA, and the University of Venda in Limpopo Province, South Africa have teamed up to develop innovative, practical, and cost-effective strategies to control waterborne diseases. This program has led to a fruitful exchange of knowledge and expertise, resulting in innovative approaches to solving the most challenging problems in developing countries, such as the detection and disinfection of C. parvum oocysts in drinking water. Researchers in this collaborative program have revealed the disinfectant properties of silver towards C. parvum oocysts [67]. In addition, the researchers developed new laboratory methods to quantify the viability of oocysts, which, until now, was only determined by qualitative microscopic analysis of fluorogenic and excystation tests [68]. Finally, they developed and tested a new low-cost porous ceramic tablet comprising silver nanopatches for domestic water purification in resource-limited environments [34].

Further research, including studies on human health or animal infectivity models, is of course required to clearly determine the degree of efficacy against cryptosporidiosis, as the WHIL researchers plan to do. However, the preliminary results obtained are very satisfactory. Within the WHIL program, researchers have been able to exchange research and know-how between different specialties, and thus develop new disinfectants and innovative methods to determine the viability of oocysts and stop the spread of Cryptosporidium by developing new water purification technologies. Despite these advances, Cryptosporidium remains a major problem in resource-limited areas, particularly in Africa. To stop the transmission of Cryptosporidium in these areas, it is essential to address the risk factors for waterborne diseases $[66,69]$.

\subsection{Risk Factors for Waterborne Diseases in Africa \\ 4.1.1. Factors of Water Contamination}

A growing body of research has revealed the presence of Cryptosporidium oocysts in all kinds of waterways, including lakes, rivers, wastewater, treated effluent, and drinking water in Africa, indicating the likelihood of endemic transmission of Cryptosporidium through water. The main causes of water pollution include uncontrolled wastewater discharges, poorly managed sewage treatment plants, and contaminated runoff from densely populated areas and unhygienic settlements along rivers [8,46]. The Kathita and Kiina rivers in Kenya, well water from the Kano River in Nigeria, surface water from the Vaal Dam, treated effluent and drinking water in South Africa, and piped water in Zambia have all been found to be contaminated by Cryptosporidium oocysts. High contamination levels of Cryptosporidium Spp. in river water; water for irrigation in Kumasi, Ghana; and vegetables consumed raw highlight the potential risk of cryptosporidiosis [13,33]. Ponds, streams, wells, and tap water in Ghana; tap water in Egypt; springs, wells, tap water, and dam water in Ethiopia; unsecured streams and wells in Malawi; open water sources (e.g., ponds or streams) in Uganda; and running water in Zambia have been reported to be contaminated with this pathogen [13]. Considering that water bodies in Africa are used by both humans and domesticated and wild animals, the risk of contamination of surface waters by Cryptosporidium excretion from these different entities is greatly increased. The fact that human and animal isolates can survive for a long period of time in all environmental waters poses a considerable health threat to local populations associated with the use of these receiving water bodies for drinking, recreation and agriculture when the quality of streams and tap water supplied to homes is unsafe, poor or unacceptable for human consumption [64]. 


\subsubsection{Factors Relating to Hazardous Practices}

A number of articles refer to risky behaviors that lead to the contamination of water systems through people's fecal waste, thus causing protozoan threats. Uncontrolled sewage dumping is a major risk that contributes to the prevalence of protozoa in water sources. In Uganda, the discharge of sewage directly into water bodies by hotels and fishing communities, the use of shallow toilets, and the discharge of wild and domestic animal excreta from the land into the water are all factors responsible for the contamination of natural water bodies (rivers, lakes, and canals) and tap water supplies with parasitic Amoeba and Cryptosporidium Spp. in ground defecation, sewage disposal, and the use of pit toilets, which are the main means of human-to-human spread of oocysts [68]. Half of the African population, particularly in sub-Saharan Africa, still use pit latrines as a method of excreta disposal, especially in developing countries [70]. The lack of waste treatment systems puts people at risk of severe gastroenteritis [71]. The consumption of spring water without any prior treatment is also a common practice among the Cameroonian population. In Yaunde Cameroon, the results of studies on water pollution in the Mingoa River (springs and wells) also confirm the influence of widespread urbanization and the practice of traditional pit toilets on the health of the population, as well as its relationship with the $40 \%$ prevalence of diarrhea and parasitic infestation [71]. As human activities increase, the water supply will be inadequate and sanitation facilities will be insufficient. Rapid population growth has led to the pollution of municipal lakes with a high accumulation of Cryptosporidium.

\subsubsection{Climate Change Factor}

While climate change may influence microbiological water quality and water-related disease, studies show considerable uncertainty about the nature of particular impacts, and when and where they will be most apparent. However, in order to assess the likely consequences for human health, it is essential to examine society's resilience to changing water quality. Understanding these adaptive potentials is crucial to determining the likely influence of climate change [72]. Climate change has a number of potential influences on water conditioning, and it is known that higher temperatures favor the implementation of biological water treatment methods [73]. A study on the impacts of climate change on surface water contamination found that climate change is likely to increase the risk associated with drinking water consumption, particularly during extreme weather events $[73,74]$. It was argued that the pathogenic risk would increase mainly due to higher temperatures and extreme precipitation events. Climate change poses a serious threat to the security of access to drinking water in Africa [75]. Increasingly erratic rainfall patterns are likely to affect freshwater supplies. Some parts of Africa have already been drier for a century (e.g., the Sahel) and, in the coming years, climate change is likely to expand the area affected by drought, doubling the frequency of extreme droughts and increasing their average duration by a factor of six [13]. Climate change will also increase malnutrition problems in Africa, as it will lead to changes in crop yields, higher food prices, and, thus, reduced food availability, reduced calorie availability, and increased child malnutrition in Africa. Cryptosporidium levels in African surface waters may also increase with population growth [13].

\subsubsection{Sociological and Economic Factors}

Poverty and illiteracy rates prevent people from being aware of the seriousness of untreated water consumption and domestic use, and the dangers of some of the practices that facilitate the transmission of diarrheal diseases [76]. As the phenomenon of large families is widely present in the African community, the demography has increased considerably, reducing the financial means per person and per family [77]. As a result, malnutrition is increasing in families, with children being the target. The lack of health education and personal hygiene programs leads to an increase in protozoan infections and the proliferation of diarrheal diseases [13]. 
Lack of sanitation and hygiene; reliance on open defecation practices; and the nonexistence of practices, such as handwashing with soap, all put children at increased risk. In Ethiopia, for example, only 19.5 per cent of Ethiopian households have access to sanitation facilities, while 80.5 per cent of households lack good hygiene practices [78]. In conclusion, poor families remain unhealthy, leading to economic instability and social marginalization [28]. Sociological and economic issues are important risk factors for contracting diarrheal diseases caused by Cryptosporidium [38].

\subsubsection{Factors Relating to the Political System}

The percentage of transmissibility of the parasite in Africa still remain a concern unless control and management measures are put in place, or important political and financial decisions are taken to make the surveillance system more effective and efficient. The political system is a key factor in the management and protection of public health in Africa. However, African leaders are unable to find a compromise to meet the challenges of building appropriate sanitation and hygiene infrastructure. There is a severe shortage of qualified health professionals and laboratories. African populations also lack transport and communication infrastructure [76]. As a result of these shortcomings, many patients have problems seeking treatment and have no choice but to resort to traditional remedies to cure diarrhea. Such practices certainly prevent accurate diagnosis and underestimate the prevalence of infectious diseases. Civil conflict and government corruption are factors that affect the long-term health of populations. These factors result in loss of life, especially among children and women [79]. Violent dictatorial regimes, conflicts, and wars in Africa, as well as unfulfilled political goals, have disrupted the health and education system and increased the prevalence of gastrointestinal diseases. Under conditions of corruption and war, agricultural facilities are lacking, resulting in food and water rationing. As a result, chronic hunger and malnutrition develop, leading to increased morbidity and mortality [80]. These factors are beyond the scope of the scientific community or individuals. Policy makers need to establish more humane rules and be more conscious of their decisions in order to justify and ensure a fair distribution of financial resources.

\section{Conclusions and Current and Future Challenges}

This paper presents the results of a review on emerging waterborne pathogens in Africa and specifically on Cryptosporidium. We reviewed 68 papers from indexed journals. The main results of the study are as follows. Several pathogenic microorganisms in Africa are likely to be threats to public health, in particular Cryptosporidium. Risk factors related to the consequences of climate change; social and behavioral factors of local populations; water problems; geographical positions that can cause isolation; and inequalities caused by the lack of transparency of African states in the distribution of financial resources are current and future challenges that African governments should address.

Although cryptosporidiosis is a major source of diarrheal disease worldwide, particularly in Africa, there is no effective treatment for it due to a perceived limited market. The sequencing of the genomes of C. parvum and C. hominis are advances that could identify new molecular targets for drug development. Due to the lack of treatment, especially for Cryptosporidiosis, high-level community awareness, policy formulation, and regular surveillance are essential factors in limiting the waterborne, zoonotic, and anthroponotic spread of Cryptosporidiosis [22,81]. These actions can only be taken if African leaders commit to providing communities with safe drinking water, improving sanitation by connecting people to sewers, and improving wastewater treatment. Community awareness programs on water safety, personal hygiene, and water treatment should be implemented. The achievement of these goals is conditional on the fight against malnutrition and a significant reduction in HIV rates in African populations. Unfortunately, the majority of African governments have not invested sufficient funds and resources to ensure that malnutrition and HIV are addressed and many HIV prevention services still do not reach most of the people who need them, largely due to staff shortages and the poor geographical distri- 
bution of existing services to those who need them most [82,83]. Despite the Millennium Development Goal of halving hunger by 2030, major failures remain in Africa. African authorities, on the other hand, have an interest in recognizing the future risks of waterborne protozoan diseases and responding quickly and effectively, because water-related crises will occur in Africa when African leaders do not have the skills and infrastructure to deal with them. As a result, African populations will use alternative water sources without adequate treatment or migrate to other countries. Disease and malnutrition will increase and waterborne protozoa will multiply. If the right decisions are not taken, Africa is likely to face more complex situations in the future. Only then can the catastrophic effects of waterborne diseases and their future consequences be mitigated [84]. Establishing a surveillance mechanism would be one of the first steps to control protozoan infections and improve community health in developing countries [48]. It is also recommended to initiate international collaboration against waterborne protozoan pathogens and to define a standardized reporting scheme. Seasonal patterns and distributions of different pathogens in Africa should also be assessed. This is particularly important given that adverse climatic events resulting from climate change are occurring more regularly on a global scale, which may lead to large outbreaks of waterborne infectious diseases [47]. Determining the molecular characteristics of Cryptosporidium should also be one of the priorities as molecular methods allow genetic determination of parasites isolated from water which can help determine the source of contamination. Drug development is essential for children suffering from diarrhea and malnutrition in Africa, as existing drugs against Cryptosporidium are mostly ineffective due to a poorly understood host-parasite interface $[81,83]$.

Author Contributions: G.O.M.K.M. had the original idea, prepared the original draft of the manuscript, and revised and edited it. I.E.B., G.O.M.K.M. and E.C.R. revised and edited the manuscript. All authors have read and agreed to the published version of the manuscript.

Funding: This research received no external funding.

Institutional Review Board Statement: Not applicable.

Informed Consent Statement: Not applicable.

Conflicts of Interest: The authors declare no conflict of interest.

\section{References}

1. Bryce, J.; Boschi-Pinto, C.; Shibuya, K.; Black, R.E.; WHO Child Health Epidemiology Reference Group. WHO estimates of the causes of death in children. Lancet 2005, 365, 1147-1152. [CrossRef]

2. Oaks, S.C., Jr.; Shope, R.E.; Lederberg, J. (Eds.) Emerging Infections: Microbial Threats to Health in the United States; National Academies Press: Washington, DC, USA, 1992.

3. Baldursson, S.; Karanis, P. Waterborne transmission of protozoan parasites: Review of worldwide outbreaks-An update 2004-2010. Water Res. 2011, 45, 6603-6614. [CrossRef]

4. Feng, Y.; Xiao, L. Zoonotic Potential and Molecular Epidemiology of Giardia Species and Giardiasis. Clin. Microbiol. Rev. 2011, 24, 110-140. [CrossRef]

5. Bouzid, M.; Kintz, E.; Hunter, P.R. Risk factors for Cryptosporidium infection in low and middle income countries: A systematic review and meta-analysis. PLoS Negl. Trop. Dis. 2018, 12, e0006553. [CrossRef]

6. Ongerth, J.E.; Karanis, P. Cryptosporidium \& Giardia in Water-Key Features and Basic Principles for Monitoring \& Data Analysis. Proceedings 2018, 2, 691. [CrossRef]

7. Dungeni, M.; Momba, M. The abundance of Cryptosporidium and Giardia spp. in treated effluents produced by four wastewater treatment plants in the Gauteng Province of South Africa. Water SA 2010, 36. [CrossRef]

8. Uneke, C.J.; Ogbu, O. Potential for Parasite and Bacteria Transmission by Paper Currency in Nigeria. J. Environ. Health 2007, 69, 54-62. [PubMed]

9. Khabo-Mmekoa, C.M.N.; Momba, M.N.B. The Impact of Social Disparities on Microbiological Quality of Drinking Water Supply in Ugu District Municipality of Kwazulu-Natal Province, South Africa. Int. J. Environ. Res. Public Health 2019, 16, 2972. [CrossRef] [PubMed]

10. Levy, K.; Smith, S.M.; Carlton, E.J. Climate Change Impacts on Waterborne Diseases: Moving Toward Designing Interventions. Curr. Environ. Health Rep. 2018, 5, 272-282. [CrossRef] [PubMed]

11. Guerrant, R.L.; Bolick, D.T.; Swann, J.R. Modeling Enteropathy or Diarrhea with the Top Bacterial and Protozoal Pathogens: Differential Determinants of Outcomes. ACS Infect. Dis. 2021, 7, 1020-1031. [CrossRef] 
12. Tichkule, S.; Jex, A.R.; van Oosterhout, C.; Sannella, A.R.; Krumkamp, R.; Aldrich, C.; Maiga-Ascofare, O.; Dekker, D.; Lamshöft, M.; Mbwana, J.; et al. Comparative genomics revealed adaptive admixture in Cryptosporidium hominis in Africa. Microb. Genomics 2021, 7. [CrossRef] [PubMed]

13. Squire, S.A.; Ryan, U. Cryptosporidium and Giardia in Africa: Current and future challenges. Parasit. Vectors 2017, $10,195$. [CrossRef]

14. Kganyago, M.; Mhangara, P. The Role of African Emerging Space Agencies in Earth Observation Capacity Building for Facilitating the Implementation and Monitoring of the African Development Agenda: The Case of African Earth Observation Program. ISPRS Int. J. Geo-Inform. 2019, 8, 292. [CrossRef]

15. Magwaza, N.; Nxumalo, E.; Mamba, B.; Msagati, T. The Occurrence and Diversity of Waterborne Fungi in African Aquatic Systems: Their Impact on Water Quality and Human Health. Int. J. Environ. Res. Public Health 2017, 14, 546. [CrossRef] [PubMed]

16. Bramer, W.M.; Rethlefsen, M.L.; Kleijnen, J.; Franco, O.H.; Bramer, W.M.; Rethlefsen, M.L.; Kleijnen, J.; Franco, O.H. Optimal database combinations for literature searches in systematic reviews: A prospective exploratory study. Syst. Rev. 2017, 6, 1-12. [CrossRef]

17. Vandenbroucke, J.P.; von Elm, E.; Altman, D.G.; Gøtzsche, P.C.; Mulrow, C.D.; Pocock, S.J.; Poole, C.; Schlesselman, J.J.; Egger, M. Strengthening the Reporting of Observational Studies in Epidemiology (STROBE): Explanation and Elaboration. PLoS Med. 2007, 4, e297. [CrossRef]

18. Tyzzer, E.E. A sporozoan found in the peptic glands of the common mouse. Exp. Biol. Med. 1907, 5, 12-13. [CrossRef]

19. Levine, N.D. The Protozoan Phylum Apicomplexa (Vols 1 and 2); CRC Press: Boca Raton, FL, USA, 1988.

20. Checkley, W.; White, A.C.; Jaganath, D.; Arrowood, M.J.; Chalmers, R.M.; Chen, X.-M.; Fayer, R.; Griffiths, J.K.; Guerrant, R.L.; Hedstrom, L.; et al. A review of the global burden, novel diagnostics, therapeutics, and vaccine targets for Cryptosporidium. Lancet Infect. Dis. 2015, 15, 85-94. [CrossRef]

21. Tenter, A.M.; Barta, J.R.; Beveridge, I.; Duszynski, D.W.; Mehlhorn, H.; Morrison, D.A.; Andrew Thompson, R.; Conrad, P.A. The conceptual basis for a new classification of the coccidia. Int. J. Parasitol. 2002, 32, 595-616. [CrossRef]

22. Thompson, R.C.A.; Olson, M.E.; Zhu, G.; Enomoto, S.; Abrahamsen, M.S.; Hijjawi, N.S. Cryptosporidium and Cryptosporidiosis. Adv. Parasitol. 2005, 59, 77-158.

23. FAO; WHO. Multicriteria-Based Ranking for Risk Management of Food-Borne Parasites; World Health Organization: Geneva, Switzerland, 2014.

24. Traub, R.J.; Monis, P.T.; Robertson, I.; Irwin, P.; Mencke, N.; Thompson, R.C.A. Epidemiological and molecular evidence supports the zoonotic transmission of Giardia among humans and dogs living in the same community. Parasitology 2004, 128, $253-262$. [CrossRef] [PubMed]

25. Koh, W.; Clode, P.L.; Monis, P.; Thompson, R.A. Multiplication of the waterborne pathogen Cryptosporidium parvum in an aquatic biofilm system. Parasit. Vectors 2013, 6, 270. [CrossRef] [PubMed]

26. Koh, W.; Thompson, A.; Edwards, H.; Monis, P.; Clode, P.L. Extracellular excystation and development of Cryptosporidium: Tracing the fate of oocysts within Pseudomonas aquatic biofilm systems. BMC Microbiol. 2014, 14, 281. [CrossRef] [PubMed]

27. Szostakowska, B.; Kruminis-Lozowska, W.; Racewicz, M.; Knight, R.; Tamang, L.; Myjak, P.; Graczyk, T.K. Cryptosporidium parvum and Giardia lamblia Recovered from Flies on a Cattle Farm and in a Landfill. Appl. Environ. Microbiol. 2004, 70, 3742-3744. [CrossRef]

28. Karanis, P.; Kourenti, C.; Smith, H. Waterborne transmission of protozoan parasites: A worldwide review of outbreaks and lessons learnt. J. Water Health 2007, 5, 1-38. [CrossRef]

29. Nyarango, R.M.; Aloo, P.A.; Kabiru, E.W.; Nyanchongi, B.O. The risk of pathogenic intestinal parasite infections in Kisii Municipality, Kenya. BMC Public Health 2008, 8, 237. [CrossRef]

30. Thompson, R.C.A.; Smith, A. Zoonotic enteric protozoa. Vet. Parasitol. 2011, 182, 70-78. [CrossRef]

31. Sharma, A.; Johri, B.N. Growth promoting influence of siderophore-producing Pseudomonas strains GRP3A and PRS9 in maize (Zea mays L.) under iron limiting conditions. Microbiol. Res. 2003, 158, 243-248. [CrossRef] [PubMed]

32. Ostroff, S.M.; Spiegel, R.A.; Feinberg, J.; Benson, C.A.; Horsburgh, C.R. Preventing Disseminated Mycobacterium avium Complex Disease in Patients Infected with Human Immunodeficiency Virus. Clin. Infect. Dis. 1995, 21, S72-S76. [CrossRef]

33. Wamae, C.N.; Wanyiri, J.W.; Kanyi, H.; Steen, A.; Ngugi, P.; O'Connor, R.; Maina, S.; Mwamburi, M.; Wang, D.E.; Ward, H.D.; et al Cryptosporidiosis in HIV / AIDS Patients in Kenya: Clinical Features, Epidemiology, Molecular Characterization and Antibody Responses. Am. J. Trop. Med. Hyg. 2014, 91, 319-328. [CrossRef]

34. Helmy, Y.A.; Von Samson-Himmelstjerna, G.; Nöckler, K.; Zessin, K.-H. Frequencies and spatial distributions of Cryptosporidium in livestock animals and children in the Ismailia province of Egypt. Epidemiol. Infect. 2015, 143, 1208-1218. [CrossRef]

35. Wumba, R.D.; Zanga, J.; Mbanzulu, K.M.; Mandina, M.N.; Kahindo, A.K.; Aloni, M.N.; Ekila, M.B. Cryptosporidium identification in HIV-Infected Humans. Experience from Kinshasa, the Democratic Republic of Congo. Acta Parasitol. 2015, 60, 638-644. [CrossRef]

36. Gendrel, D.; Treluyer, J.M.; Richard-Lenoble, D. Parasitic diarrhea in normal and malnourished children. Fundam. Clin. Pharmacol. 2003, 17, 189-197. [CrossRef]

37. Gubbels, S.-M.; Kuhn, K.G.; Larsson, J.T.; Adelhardt, M.; Engberg, J.; Ingildsen, P.; Hollesen, L.W.; Muchitsch, S.; Mølbak, K.; Ethelberg, S. A waterborne outbreak with a single clone of Campylobacter jejuni in the Danish town of Køge in May 2010. Scand. J. Infect. Dis. 2012, 44, 586-594. [CrossRef] 
38. Mengist, H.M.; Taye, B.; Tsegaye, A. Intestinal Parasitosis in Relation to CD4+T Cells Levels and Anemia among HAART Initiated and HAART Naive Pediatric HIV Patients in a Model ART Center in Addis Ababa, Ethiopia. PLoS ONE 2015, 10, e0117715. [CrossRef]

39. Breurec, S.; Vanel, N.; Bata, P.; Chartier, L.; Farra, A.; Favennec, L.; Franck, T.; Giles-Vernick, T.; Gody, J.-C.; Luong Nguyen, L.B.; et al. Etiology and Epidemiology of Diarrhea in Hospitalized Children from Low Income Country: A Matched Case-Control Study in Central African Republic. PLoS Negl. Trop. Dis. 2016, 10, e0004283. [CrossRef]

40. Mondal, D.; Minak, J.; Alam, M.; Liu, Y.; Dai, J.; Korpe, P.; Liu, L.; Haque, R.; Petri, W.A. Contribution of Enteric Infection, Altered Intestinal Barrier Function, and Maternal Malnutrition to Infant Malnutrition in Bangladesh. Clin. Infect. Dis. 2012, 54, 185-192. [CrossRef] [PubMed]

41. Bushen, O.Y.; Kohli, A.; Pinkerton, R.C.; Dupnik, K.; Newman, R.D.; Sears, C.L.; Fayer, R.; Lima, A.A.M.; Guerrant, R.L. Heavy cryptosporidial infections in children in northeast Brazil: Comparison of Cryptosporidium hominis and Cryptosporidium parvum. Trans. R. Soc. Trop. Med. Hyg. 2007, 101, 378-384. [CrossRef] [PubMed]

42. Holubová, N.; Sak, B.; Horčičková, M.; Hlásková, L.; Květoňová, D.; Menchaca, S.; McEvoy, J.; Kváč, M. Cryptosporidium avium n. sp. (Apicomplexa: Cryptosporidiidae) in birds. Parasitol. Res. 2016, 115, 2243-2251. [CrossRef] [PubMed]

43. Costa, J.; Cruz, C.; Eiras, J.C.; Saraiva, A. Characterization of a Cryptosporidium scophthalmi-like isolate from farmed turbot (Scophthalmus maximus) using histological and molecular tools. Dis. Aquat. Organ. 2016. Available online: https: / / scholar.google.com.hk/ citations?view_op=view_citation\&hl=zh-CN\&user=k4Ogs2QAAAAJ\&cstart=20\&pagesize=80 \&sortby=pubdate\&citation_for_view=k4Ogs2QAAAAJ:Zph67rFs4hoC (accessed on 10 September 2021).

44. Zahedi, A.; Paparini, A.; Jian, F.; Robertson, I.; Ryan, U. Public health significance of zoonotic Cryptosporidium species in wildlife: Critical insights into better drinking water management. Int. J. Parasitol. Parasites Wildl. 2016, 5, 88-109. [CrossRef]

45. Cacciò, S.M.; Thompson, R.C.A.; McLauchlin, J.; Smith, H.V. Unravelling Cryptosporidium and Giardia epidemiology. Trends Parasitol. 2005, 21, 430-437. [CrossRef] [PubMed]

46. Ajeagah, G.; Njine, T.; Foto, S.; Bilong, C.F.B.; Karanis, P. Tropical Eutrophic Lake. Int. J. Environ. Sci. Technol. 2007, 4, 223-232. [CrossRef]

47. Aldeyarbi, H.M.; Abu El-Ezz, N.M.T.; Karanis, P. Cryptosporidium and cryptosporidiosis: The African perspective. Environ. Sci. Pollut. Res. 2016, 23, 13811-13821. [CrossRef] [PubMed]

48. Savioli, L.; Smith, H.; Thompson, A. Giardia and Cryptosporidium join the 'Neglected Diseases Initiative'. Trends Parasitol. 2006, 22, 203-208. [CrossRef] [PubMed]

49. Ghoneim, N.H.; Hassanain, M.A.; Hamza, D.A.; Shaapan, R.M.; Draz, S.H. Prevalence and molecular epidemiology of Cryptosporidium infection in calves and hospitalized children in Egypt. Res. J. Parasitol. 2017, 12, 19-26.

50. Boulter-Bitzer, J.I.; Lee, H.; Trevors, J.T. Molecular targets for detection and immunotherapy in Cryptosporidium parvum. Biotechnol. Adv. 2007, 25, 13-44. [CrossRef]

51. MacFarlane, D.E.; Horner-Bryce, J. Cryptosporidiosis in Wellnourished and Malnourished Children. Acta Paediatr. 1987, 76, 474-477. [CrossRef]

52. Gutiérrez-Aguirre, I.; Rački, N.; Dreo, T.; Ravnikar, M. Droplet Digital PCR for Absolute Quantification of Pathogens. Methods Mol. Biol. 2015, 1302, 331-347. [CrossRef]

53. Pomari, E.; Piubelli, C.; Perandin, F.; Bisoffi, Z. Digital PCR: A new technology for diagnosis of parasitic infections. Clin. Microbiol. Infect. 2019, 25, 1510-1516. [CrossRef]

54. Yang, R.; Paparini, A.; Monis, P.; Ryan, U. Comparison of next-generation droplet digital PCR (ddPCR) with quantitative PCR (qPCR) for enumeration of Cryptosporidium oocysts in faecal samples. Int. J. Parasitol. 2014, 44, 1105-1113. [CrossRef]

55. Guo, C.; Zhou, Z.; Wen, Z.; Liu, Y.; Zeng, C.; Xiao, D.; Ou, M.; Han, Y.; Huang, S.; Liu, D.; et al. Global Epidemiology of Dengue Outbreaks in 1990-2015: A Systematic Review and Meta-Analysis. Front. Cell. Infect. Microbiol. 2017, 7, 317. [CrossRef] [PubMed]

56. Wang, W.; Zhao, Y.; Bai, H.; Zhang, T.; Ibarra-Galvan, V.; Song, S. Methylene blue removal from water using the hydrogel beads of poly(vinyl alcohol)-sodium alginate-chitosan-montmorillonite. Carbohydr. Polym. 2018, 198, 518-528. [CrossRef] [PubMed]

57. Gilchrist, C.A.; Cotton, J.A.; Burkey, C.; Arju, T.; Gilmartin, A.; Lin, Y.; Ahmed, E.; Steiner, K.; Alam, M.; Ahmed, S.; et al. Genetic Diversity of Cryptosporidium hominis in a Bangladeshi Community as Revealed by Whole-Genome Sequencing. J. Infect. Dis. 2018, 218, 259-264. [CrossRef] [PubMed]

58. Abubakar, I.; Aliyu, S.H.; Arumugam, C.; Usman, N.K.; Hunter, P.R. Treatment of cryptosporidiosis in immunocompromised individuals: Systematic review and meta-analysis. Br. J. Clin. Pharmacol. 2007, 63, 387-393. [CrossRef] [PubMed]

59. Amadi, B.; Mwiya, M.; Sianongo, S.; Payne, L.; Watuka, A.; Katubulushi, M.; Kelly, P. High dose prolonged treatment with nitazoxanide is not effective for cryptosporidiosis in HIV positive Zambian children: A randomised controlled trial. BMC Infect. Dis. 2009, 9, 195. [CrossRef] [PubMed]

60. Miao, Y.M.; Awad-El-Kariem, F.M.; Franzen, C.; Ellis, D.S.; M??ller, A.; Counihan, H.M.; Hayes, P.J.; Gazzard, B.G. Eradication of Cryptosporidia and Microsporidia Following Successful Antiretroviral Therapy. J. Acquir. Immune Defic. Syndr. 2000, 124-129. [CrossRef]

61. Carr, A.; Marriott, D.; Field, A.; Vasak, E.; Cooper, D.A. Treatment of HIV-1-associated microsporidiosis and cryptosporidiosis with combination antiretroviral therapy. Lancet 1998, 351, 256-261. [CrossRef]

62. Miyamoto, Y.; Eckmann, L. Drug Development Against the Major Diarrhea-Causing Parasites of the Small Intestine, Cryptosporidium and Giardia. Front. Microbiol. 2015, 6, 1208. [CrossRef] [PubMed] 
63. Kumpel, E.; Nelson, K.L. Intermittent Water Supply: Prevalence, Practice, and Microbial Water Quality. Environ. Sci. Technol. 2016, 50, 542-553. [CrossRef] [PubMed]

64. Abd El-Salam, M.M. Assessment of water quality of some swimming pools: A case study in Alexandria, Egypt. Environ. Monit. Assess. 2012, 184, 7395-7406. [CrossRef] [PubMed]

65. Ndur, S.A.; Kuma, J.S.Y.; Buah, W.K.; Galley, J.Y. Quality of Sachet Water Produced at Tarkwa, Ghana. Ghana Min. J. 2015, 15, 22-34. [CrossRef]

66. Sente, C.; Erume, J.; Naigaga, I.; Mulindwa, J.; Ochwo, S.; Magambo, P.K.; Namara, B.G.; Kato, C.D.; Sebyatika, G.; Muwonge, K.; et al. Prevalence of pathogenic free-living amoeba and other protozoa in natural and communal piped tap water from Queen Elizabeth protected area, Uganda. Infect. Dis. Poverty 2016, 5, 68. [CrossRef] [PubMed]

67. Meutchieye, F.; Kouam, M.K.; Miegoué, E.; Nguafack, T.T.; Tchoumboué, J.; Téguia, A.; Théodoropoulos, G. A survey for potentially zoonotic gastrointestinal parasites in domestic cavies in Cameroon (Central Africa). BMC Vet. Res. 2017, 13, 196. [CrossRef] [PubMed]

68. Delahoy, M.J.; Wodnik, B.; McAliley, L.; Penakalapati, G.; Swarthout, J.; Freeman, M.C.; Levy, K. Pathogens transmitted in animal feces in low- and middle-income countries. Int. J. Hyg. Environ. Health 2018, 221, 661-676. [CrossRef] [PubMed]

69. Conan, A.; O’Reilly, C.E.; Ogola, E.; Ochieng, J.B.; Blackstock, A.J.; Omore, R.; Ochieng, L.; Moke, F.; Parsons, M.B.; Xiao, L.; et al. Animal-related factors associated with moderate-to-severe diarrhea in children younger than five years in western Kenya: A matched case-control study. PLoS Negl. Trop. Dis. 2017, 11, e0005795. [CrossRef]

70. Anne Alexander, K.; Herbein, J.; Zajac, A. The Occurrence of Cryptosporidium and Giardia Infections Among Patients Reporting Diarrheal Disease in Chobe District, Botswana. Adv. Infect. Dis. 2012, 2, 143-147. [CrossRef]

71. Elfadaly, H.A.; Hassanain, N.A.; Hassanain, M.A.; Barakat, A.M.; Shaapan, R.M. Evaluation of primitive ground water supplies as a risk factor for the development of major waterborne zoonosis in Egyptian children living in rural areas. J. Infect. Public Health 2018, 11, 203-208. [CrossRef]

72. Cann, K.F.; Thomas, D.R.; Salmon, R.L.; Wyn-Jones, A.P.; Kay, D. Extreme water-related weather events and waterborne disease. Epidemiol. Infect. 2012, 141, 671-686. [CrossRef]

73. Nichols, G.; Lake, I.; Heaviside, C. Climate Change and Water-Related Infectious Diseases. Atmosphere 2018, 9, 385. [CrossRef]

74. Lake, I.R.; Bentham, G.; Kovats, R.S.; Nichols, G.L. Effects of weather and river flow on cryptosporidiosis. J. Water Health 2005, 3, 469-474. [CrossRef]

75. Tigabu, E.; Petros, B.; Endeshaw, T. Prevalence of Giardiasis and Cryptosporidiosis among children in relation to water sources in Selected Village of Pawi Special District in Benishangul-Gumuz Region, Northwestern Ethiopia. Ethiop. J. Health Dev. 2011, 24. [CrossRef]

76. Ahmed, S.A.; Guerrero Flórez, M.; Karanis, P. The impact of water crises and climate changes on the transmission of protozoan parasites in Africa. Pathog. Glob. Health 2018, 112, 281-293. [CrossRef] [PubMed]

77. Guerrant, D.I.; Moore, S.R.; Lima, A.A.M.; Patrick, P.D.; Schorling, J.B.; Guerrant, R.L. Association of early childhood diarrhea and cryptosporidiosis with impaired physical fitness and cognitive function four-seven years later in apoor urban community in northeast Brazil. Am. J. Trop. Med. Hyg. 1999, 61, 707-713. [CrossRef] [PubMed]

78. Atnafu, T.; Kassa, H.; Keil, C.; Fikrie, N.; Leta, S.; Keil, I. Presence, Viability and Determinants of Cryptosporidium Oocysts and Giardia Cysts in the Addis Ababa Water Supply and Distribution System. Water Qual. Expo. Health 2012, 4, 55-65. [CrossRef]

79. Dos Santos, S.; Adams, E.A.; Neville, G.; Wada, Y.; de Sherbinin, A.; Mullin Bernhardt, E.; Adamo, S.B. Urban growth and water access in sub-Saharan Africa: Progress, challenges, and emerging research directions. Sci. Total Environ. 2017, 607-608, 497-508. [CrossRef]

80. Uchendu, F.N. Hunger influenced life expectancy in war-torn Sub-Saharan African countries. J. Health Popul. Nutr. 2018, 37, 11. [CrossRef]

81. Mor, S.M.; Tzipori, S. Cryptosporidiosis in Children in Sub-Saharan Africa: A Lingering Challenge. Clin. Infect. Dis. 2008, 47, 915-921. [CrossRef]

82. Thomas, K.M.; Charron, D.F.; Waltner-Toews, D.; Schuster, C.; Maarouf, A.R.; Holt, J.D. A role of high impact weather events in waterborne disease outbreaks in Canada, 1975-2001. Int. J. Environ. Health Res. 2006, 16, 167-180. [CrossRef] [PubMed]

83. Efstratiou, A.; Ongerth, J.E.; Karanis, P. Waterborne transmission of protozoan parasites: Review of worldwide outbreaks-An update 2011-2016. Water Res. 2017, 114, 14-22. [CrossRef] [PubMed]

84. Guillot, E.; Loret, J.F. Waterborne Pathogens: Review for the Drinking Water Industry; Publishing Alliance House: London, UK, 2009. 